Trinity University Digital Commons@ Trinity

Modern Languages and Literatures Faculty

Research

Modern Languages and Literatures Department

4-2008

\title{
The Play of Means and Ends: Justice in Lope's Fuenteovejuna
}

Matthew D. Stroud

TrinityUniversity, mstroud@trinity.edu

Follow this and additional works at: http://digitalcommons.trinity.edu/mll_faculty

Part of the Modern Languages Commons

\section{Repository Citation}

“The Play of Means and Ends: Justice in Lope’s Fuenteovejuna." Neophilologus 92.2 (2008): 247-62.

This Article is brought to you for free and open access by the Modern Languages and Literatures Department at Digital Commons @ Trinity. It has been accepted for inclusion in Modern Languages and Literatures Faculty Research by an authorized administrator of Digital Commons @ Trinity. For more information, please contact jcostanz@trinity.edu. 


\title{
The Play of Means and Ends: Justice in Lope's Fuenteovejuna
}

\author{
Matthew D. Stroud
}

Published online: 25 September 2007

(C) Springer Science+Business Media B.V. 2007

\begin{abstract}
Lope's masterpiece, Fuenteovejuna, is generally considered to be a glowing endorsement of the reign of Fernando and Isabel, who represent not just a glorious and hopeful Spanish history but political acumen, justice, and the triumph of good over evil. A closer examination of several key plot elements, however, reveals that almost every time characters are called upon to make decisions, they choose the option that at best circumvents the requirements for justice and at worst actively works to the detriment of the proper administration of justice and law. This study focuses on four pivotal moments when Frondoso takes the Comendador's crossbow and threatens him; when the Comendador imprisons Frondoso and kidnaps Laurencia; when the town rises up and kills the Comendador; and when Fernando and Isabel intervene in order to reach a final verdict and concludes that the only philosophy upheld in these instances is one not based on notions of ideal justice but on the Machiavellian notion that the right action is the one that upholds the political power of the state.
\end{abstract}

Criticism of Lope's Fuenteovejuna frequently focuses on the remarkable stand taken by the inhabitants of the village against the abuse they have suffered at the hands of the Comendador, Fernán Gómez de Guzmán. Not unsurprisingly, since great works of literature frequently do not lend themselves to encapsulated morality and tidy interpretations, the analyses of the play are all over the map. Fuenteovejuna has been said to be primarily about love, honor, platonic harmony, the inherent rights and dignity of people, the mythical archetype of heroism, revolutionary and democratic politics, and fascism, just

\footnotetext{
M. D. Stroud ( $₫)$

Department of Modern Languages, Trinity University, One Trinity Place, San Antonio, TX 78212, USA

e mail: mstroud@trinity.edu
} 
to name a few. ${ }^{1}$ Given the attention paid to the actions of all the main characters, it is somewhat surprising that even the very basic question of whether or not the play presents a unified moral, legal, and ethical point of view is in dispute. According to Herrera Moriano, "cada paso parece estar medido en ella por un criterio de legalidad preciso y claro" (p. 136), and Vossler sees the play as a reaction against injustice (p. 316), while Archer repeatedly describes the actions of the play in terms of ambiguity and paradox (pp. 114, 115, 117), and Carter notes that all laws, based as they are in language, "can be made to seem either just or unjust" and are susceptible to misinterpretation and ambiguity (p. 330). Lurking beneath the surface of most of these perspectives, if not manifest in the discussion, are various, and often conflicting, notions of justice.

A quick overview of the concept of justice will reveal that it is an extremely slippery concept, difficult to define, and dependent upon a host of contingent factors. ${ }^{2}$ Idealist justice is related to virtue, sometimes considered in the abstract and sometimes only rendered useful as a principle guiding the way people treat each other. Plato conceived of Absolute Justice as a function of good and beauty (Forastieri 1972, p. 92). Utilitarian justice is a function of the proportional distribution of rewards and punishments (distributive justice), rendering to all people that which is due them, or the fulfillment of the terms of a contract (commutative justice). Internal justice is the conformity of the will of the individual to the law and thus is the object of morality; external justice is the conformity of one's actions to the law and thus is the object of jurisprudence. Personal justice sometimes looks like revenge (thus the interest in parsing the terms in such plays as Lope's El castigo sin venganza); social justice promotes equality and freedom and strives to liberate individuals and groups from oppression. For Spinoza, justice is a combination of the will of God and the power of the sovereign; by this definition it is not surprising that Castro (1909, p. 5) can assert that the monarch is the guarantor of justice for the people. When seen through different lenses, justice can thus be seen to be a function of truth, power, reason, the judgment of a disinterested higher authority, and even the pragmatic notion that the ends justify the means. The different critics who have studied the issue naturally take different approaches to the concept of justice. Fiore (1966, pp. 76, 79), for example, reads the play as a restoration of peace and harmony through natural law by means of both retributive and distributive justice; Wardropper, obtaining his definition from the comedia as a genre, notes that justice is a function of valor, honor, courtesy, nobility, and love (Wardropper 1956, pp. 161 162, p. 171). So complicated is the concept of justice and its application that Forastieri resorts to a structuralist model in which divine justice, royal justice, and the people's justice are all represented by different letters, concluding that different actions in the play can be represented by different

\footnotetext{
${ }^{1}$ This article does not intend to offer a review of the critical literature on Fuenteovejuna. Readers interested in a complete discussion of critical opinion regarding this play are directed to studies by others, especially Kirschner (1977), Forastieri Braschi, Herrera Montero, and Larson (2001).

${ }^{2}$ Except where otherwise noted, the general concepts and definitions here can be found under the following headings in the Encyclopedia of Philosophy: "Justice," "Idealism," "History of Philosophy of Law," "Problems of Philosophy of Law," "Benedict (Baruch) Spinoza."
} 
"formulas" of the these letters (pp. 94 97). It is the thesis here than one of the aspects of Fuenteovejuna that makes it still deserving of attention is the way in which Lope pits varying concepts of justice against one another in order to tease out the areas of agreement and conflict, thus bringing to the audience much more than a simple one-dimensional morality play.

Virtually everyone agrees that Lope succeeded in depicting Fernán Gómez as a villainous troublemaker on multiple levels. Weimer states that the Comendador "violates moral, natural and civil laws in his abuses of power" (p. 179), Elman indicts him as being a "libertine, unjust lord, and traitor to King Ferdinand and Queen Isabella" (p. 449), and Forastieri notes his "progresiva represión abusiva" (p. 94). He is unwilling or unable to distinguish moral law from social custom (Carter 1977, p. 322), or to differentiate his role as a man from that as a governor (Blue 1991, p. 304). Arrogant and petty, he treats even the Maestre with condescension despite the fact that the latter outranks him (Blue 1991, p. 304). He treats his vassals even more poorly, and insists on humiliating those in a position inferior to his while refusing to entertain any notion that his actions might offend the honor of the inhabitants of Fuenteovejuna, which he believes they simply cannot possess due to their status as commoners (v. 989). ${ }^{3}$ His affronts are not just personal: he strikes at the very heart of the society by interrupting the rituals that mark the milestones of importance to the people, such as the wedding, and violating such important symbolic gestures as the exchange of gifts, in essence "disrupting the life cycle" of the community (Camino 2004, p. 383). When he strikes Esteban, the mayor of Fuenteovejuna, with his staff of office in a display of domination and anger (vv. 1635 1638), he not only attacks the villagers who have shown him such respect but also violates the dignity of another human being (Sánchez Boudy 1981, p. 760). And, of course, he is licentious and sexually abusive with the women of the village, not just deflowering them (vv. 193 195), taking them away from their homes against their will (vv. 1191 1195, 1258 1275), referring to them in odious and demeaning ways (vv. 1061 1084), and attempting to seduce them with clothing and jewelry (vv. 201204 ) or by tricking them into acceding to his desires (vv. 615 617), but assuming that the women should be flattered by his attentions (vv. 969 972, 994 998). He even asks Laurencia's father to aid him in his attempt to bed her (vv. 959 968). He is, as Elman (1996, p. 449) has pointed out, a rapist, and clearly sociopathic if we take into consideration his lack of any kind of recognition of his own wrongdoing. Unlike even the pragmatic, Machiavellian model of an overlord who is able to achieve his goals while simultaneously maintaining the good will of the governed, the Comendador's actions have created widespread unhappiness (Herrera Montero 1989, pp. 143 144); Flores notes that his subjects are miserable, "de todo contento ajenos" (v. 694). It is easy to agree with Christopher Weimer's description of the Comendador as a pharmakos who must be eliminated so that order can be restored and everyone at all levels can live in peace and harmony; ${ }^{4}$

\footnotetext{
${ }_{3}$ All citations from the play are from the edition by Maria Grazia Profeti.

${ }^{4}$ Weimer 1996, pp. 180, 182; cf. Darst 1995, pp. 247, 248, 250. Fiore likewise sees him as "the agent who initiates the chain of causality which is morally detestable, and which in the end turns back on him in the form of punishment" (p. 75) and studies the trajectory of the play in terms of the restoration of harmony as a function of the "observance of natural law" and the justice that that engenders (p. 76).
} 
there is little doubt that the final resolution of the play, including the elimination of this evil, is intended to be regarded as a happy ending. It is also important to point out, however, that he is not, as Matas has noted, a one-dimensional cartoon villain (p. 389); rather, he is to be taken seriously as a representative of the ideals and behaviors of those powerful noblemen like him arrogant, exploitative, uncaring and perhaps even a symbol of the passing of an ancien régime that sanctioned such abominable practices as the droit du seigneur. The Comendador, in his dual role as legitimate lord and immoral abuser, can be said to be simultaneously right and wrong, acting both legally and outrageously depending on whether or not one is willing to grant him the rights and privileges accorded to medieval lords. ${ }^{5}$ Likewise, the fact that the villagers suffer greatly at his hands does not mean that one needs to accept each and every response to the predations of the Comendador, even that of the Reyes Católicos, as proper, innocent, good and just. For our purposes here, let us look at four particular moments in the plot, each of which takes place in a context sure to complicate a decision regarding right and wrong, justice and injustice: when Frondoso takes the Comendador's crossbow and threatens him unless he leaves Laurencia alone; when the Comendador imprisons Frondoso and kidnaps Laurencia; when the town rises up and kills the Comendador; and when the monarchs, Fernando and Isabel, intervene in Act 3 in order to reach a final verdict.

The first act of resistance against the abuses of the Comendador comes when Frondoso takes the Comendador's crossbow and threatens him at the end of Act 1. It is quite clear from the text that, at least in Frondoso's mind, the threat of sexual violence against Laurencia, whom Frondoso loves and hopes to marry despite her denials, is real. From his point of view, Frondoso's act is an attempt to defend his fellow villager and the woman he loves. Despite widespread critical support of Frondoso's courageous defense of Laurencia, ${ }^{6}$ it is not at all certain that he has the right to threaten the life of the Comendador. First, Frondoso acts preemptively, before the Comendador has actually done any physical harm to Laurencia. Second, no system of justice allows for an individual to take matters into his own hands rather than submitting the case for adjudication to an impartial third party such as a court or the monarch. Likewise, no system of social hierarchy allows an individual to steal the weapon of the person in authority and threaten him with violence. Frondoso may have the right to appeal for justice to a higher authority (Herrera Montero 1989, p. 136), but it is not permitted for him to act on his own, disarm the Comendador by taking his property, and flee. Finally, there is the matter of Frondoso's relationship to Laurencia. He may love her deeply, but she is not related to him by either blood or marriage; they are not yet even engaged. Under the law they are strangers. Even under the looser guidelines of honor, "the friend or fiancé of an unmarried girl" has no "rights of retribution and reparation for advances forced upon her" (Carter 1977, p. 323). Thus, with this scene, Lope pits strong, basic views of justice against each other: it is a basic human reaction to step in to

\footnotetext{
5 Matas (1981, p. 390) goes so far as to accord the Comendador's position the exalted status of tragic hero, seeing in his actions those of an honorable man blined by hubris.

${ }^{6}$ Fiore 1966, p. 77. Wardropper takes this argument even further, alleging that Frondoso is too restrained and deferential to the Comendador: "Frondoso, aiming a crossbow at his lord, addresses him as 'Comendador generoso'” (p. 169).
} 
protect the people one loves but in this case it would appear that Frondoso is on shaky legal ground. Sentiment may definitely be on the side of Frondoso, but the law is on the side of the Comendador.

The Comendador, stinging from Frondoso's act of insubordination and the humiliation it caused him to have to yield to a commoner, strikes back individually against some, notably Frondoso, Laurencia, and Esteban, and collectively against all the people of the village. Frondoso is captured and held for execution, Laurencia is abducted and abused, and Esteban is assaulted when the Comendador takes his staff of office and hits him with it. Are these justified acts of punishment, or acts of personal revenge? The difference between justice and revenge is at the heart of a great deal of the gray area in this play, and perhaps a brief discussion of the two is in order. Justice, in addition to adhering to a philosophical and moral ideal of rightness, is also defined in terms of structure and process. Normally, for justice to be carried out, it must be handed down by a superior authority (a mayor, a judge, a priest) who is not party to the dispute and who has no personal interest in the outcome. Both sides must agree to abide by the decision of the judicial authority, to whom they present evidence and make the case for their point of view in open court. The judgment and the punishments must cohere with both legal statute and legal precedent: to give a harsher punishment to two people who commit the same crime is unjust. Justice, therefore, is impartial, disinterested, public, and socially prescribed. According to Mariana, as cited by Archer (1990, p. 113), justice is carried out by a group of prudent men, not an individual. ${ }^{7}$ Revenge, on the other hand, is personal. Rather than appeal to a court or magistrate, one seeking revenge takes matters into one's own hands and commits whatever "punishment" one considers fitting regardless of law, custom, or precedent. The act is sometimes committed in secret (one need only think of the title of Calderón's play, A secreto agravio, secreta venganza) and satisfies the injured ego of the perpetrator more than the prescribed tenets of a legal code.

The complications in the Comendador's response to the actions at the end of Act 1 are two. First, the line between justice and revenge is blurred when the person seeking retribution also possesses the authority to dispense justice, and Ruiz Ramón (1991, p. 48) emphasizes the muddled blending of justice and revenge in the Comendador's motivations. While the debate between justice and revenge is important from a philosophical point of view, there is little doubt that, if the altercation had occurred between Frondoso and Flores, the Comendador would have had the authority to pronounce judgment against the guilty party, even if that judgment were flawed because of corruption, bias, or insufficient evidence. (Since any system of justice is ultimately a function of human judgment and behavior, it is inherently an imperfect system. ${ }^{8}$ ) In any case, it is clear that the Comendador has the right to take action against the man who stole his property and threatened him.

\footnotetext{
7 Otis Green has studied Mariana's hierarchy of power in more detail, and noted the following hierarchy from which justice flows: God, law and justice, people, the prince (cited in Forastieri 1972, p. 93).

8 Dixon (1988, p. 166) notes the difficulty in separating guilt and innocence by citing the following emblem of Covarrubias: "es tan fauorecida la innocencia de la justicia, y tan priuilegiada, que suele ser asylo y refugio de la culpa, pues abraçandose con ella, por no lastimar al inocente, no descarga el golpe sobre el culpado."
} 
According to Carter (1977, p. 323), "Frondoso did commit a crime, which, strictly speaking, is a crime against the Maestre and his Order, and under normal circumstances, deserving of exemplary punishment." Given the text before us, however, there is simply no way to state clearly whether the Comendador is acting out of a sense of justice or a need for revenge in his dealings with Frondoso. On the one hand, despite Fiore's protestations regarding the lack of a trial (p. 78), the Comendador is clearly using the structures of a judicial system: he orders his men to arrest Frondoso, he imprisons him rather than exacting an immediate retribution himself, he declares that Frondoso's own father must pronounce the sentence against him, and Frondoso is to be hanged in public as an example to all. On the other hand, the Comendador and his men repeatedly use the language of revenge: "yo tomaré venganza / del agravio y del estorbo" (vv. 857 858). ${ }^{9}$

The second problem with the Comendador's actions arises from the fact that the Comendador chooses to punish as well those who have not harmed him. The case may be made that Mengo deserves some punishment for his having thrown rocks at the Comendador's men, but of what punishable transgressions are Laurencia, Esteban, Jacinta, and other villagers guilty? From what we know, Laurencia's and Jacinta's only offense is having rejected the Comendador's sexual advances and Esteban has refused to assist the Comendador by turning over his daughter as an offering to the Comendador's lust. For Elman, Fernán Gómez's treatment of Laurencia is a "metaphor for the usurpation of the peasants' honor by their lord" (Elman 1996, p. 451). The Comendador seems to believe that his subjects must obey all of his commands, no matter how illegal, indecent, or inappropriate. The villagers are not slaves, however, and it is perfectly reasonable for them to refuse to comply with an abusive order. They may not have the kind of honor bestowed by nobility, as the Comendador and his men note in sneering terms, but they are still human beings entitled to be treated with dignity.

There can be little disagreement with Sánchez Boudy's assertion that in this play Lope puts political power in the hands of the people (p. 760); the question is whether or not their actions are to be considered a just and legitimate response to their oppression. By far the greatest critical attention has been paid to whether or not the villagers had or did not have the right to rebel and to kill the Comendador. The excellent work done by Robin Carter and others can be summarized by two general assertions. Barrildo states unequivocally that the treatment of the villagers by the Comendador is unjust (vv. 1487 1488), and there are simply no convincing arguments to uphold the legitimacy of the Comendador's abuse of the people under his control (Carter 1977, p. 321). The question, of course, is how to fight injustice, through proper, rational, legal, and moral means, or through an additional act of injustice. Despite Gómez Moriana's unequivocal assertion that the plot of this play upholds the right of the people to resist oppression and even commit tyrannicide (p. 72), the issue of the legitimate means of resistance to an abusive ruler was in fact the subject of significant debate. Influential writers such as John of Salisbury, Bartolus, Francisco Suárez, Francisco de Vitoria, Domingo

\footnotetext{
9 Elman (1996, pp. 450 451) discusses the lex talionis, "an eye for an eye," and concludes that the Comendador's actions must be characterized as vengeance.
} 
de Soto and Juan de Mariana, among others, relied on such notable authorities as Aristotle and Saint Thomas Aquinas as they tried to establish the boundaries that delineated the correct response to abuse (see Gómez Moriana 2000, p. 75; Archer 1990, pp. 113 114; Carter 1977, pp. 315 319; Fiore 1966, pp. 77 78). It appears, however, that these revered sources did not, or could not, provide clear guidelines for a moral response to an abusive ruler. Even a single authority was not always consistent from one work to another. Aquinas, for example, is ambiguous; in one place he recommends that an oppressed people appeal to a higher authority for relief (and does not allow for the possibility of tyrannicide), while in another, he appears to agree with Cicero that the assassination of Julius Caesar was justified (Archer 1990, p. 112; Carter 1977, pp. 313 315). Juan de Mariana, on the other hand, approves the death of a usurper as well as oppressive legitimate monarchs (Archer 1990, p. 112, Carter 1977, p. 317) and even mentions the case of Fuenteovejuna itself, noting that the rebellion was "perfectamente justa" (Archer 1990 , p. 113). Wardropper, somewhat surprisingly, dismisses any objective determination of justice and asserts that the villagers' actions are just per se because they are motivated by love, which trumps any counterbalancing consideration (Wardropper 1956, p. 163).

Such factors as the nature of the abuse and whether or not the ruler might be considered a tyrant were of paramount importance in determining the limits of the response of the subjects. One of the most important factors dealt with whether the tyrant was a legitimate but abusive ruler or an illegitimate usurper; in the latter case one had more options, including tyrannicide, than one had in the former case (Archer 1990, pp. 112 114; Carter 1977, p. 313). Since the Comendador was indeed the legitimate ruler of Fuenteovejuna, the villagers needed to proceed with great caution. During the meeting of the town council at the beginning of Act 3, several options are proposed: Esteban appears to want to incite the peasants to open rebellion, and the repeated uses of the terms "tiranos" (vv. 16991880 passim), "honor" (vv. 1820, 1827), and "patria" (vv. 1667, 1695) would seem to be an attempt to justify their actions in opposition to the oppression they suffer (see Ruiz Ramón 1991, pp. 56 57; Archer 1990, p. 111, pp. 114 115), while adding the idea that such a revolt would be a blow in favor of the Reyes Católicos for good measure (Carter 1977, pp. 325 326). It is clear, however, that the villagers understand how the process of justice is supposed to work: Juan Rojo suggests sending a petition to the monarchs (vv. 1674 1679). Barrildo, however, says they have no time for such issues given the larger civil war at hand, and Cuadrado suggests that the villagers should abandon their lands and the Comendador with them (Archer 1990, p. 110). All of these options, of course, are quickly swept aside as a result of Laurencia's astonishing coup de théâtre.

In her lengthy list of grievances, Laurencia intimates, but does not actually state, that she has been raped by the Comendador. Laurencia has clearly been kidnapped and she bears numerous signs of abuse: her hair, her bruises, her blood (vv. 1752 1754). In scathing terms, she indicts her father and the other men who have allowed their daughters to be abused by the evil Comendador. The mood changes instantly from calm consideration of their options to anger and ego as the men respond to being called sheep, having their masculinity impugned, and being made to feel 
deeply ashamed and dishonored. ${ }^{10}$ In other words, the sight of the "mujer violada" single-handedly derails the possibility of a response in accordance with the accepted norms of law and justice and causes the already simmering tensions to boil over (Forastieri 1972, p. 95). Indeed, Elman has noted that Laurencia's leadership in exacting revenge against the Comendador places her in the "the mirror image of her own violation" (p. 452). If further proof is needed that the popular rebellion was an act of revenge rather than an act of justice, one need look no further than the villagers' repeated use of the word "venganza" or one of its related forms (vv. 1713, 1728, 1732, 1892, 1900, 1913). As Carter has correctly asserted (1977, p. 326), the problems in the play "are not, in practice, resolved rationally, in spite of the theorists' efforts to find rational solutions" and the people's revolt represents "the complete breakdown of reason and order."11

The audience, swept up in this moment of pure human passion, may be convinced of the moral correctness of the villagers' actions, but Frondoso reveals at the end of the play that the Comendador did not have sexual relations with Laurencia (vv. 2411 2414). The revelation that she is still a virgin allows for a happy ending, since Frondoso can now still marry her without compromising anyone's honor (Archer 1990, p. 117), but this turn of events creates such moral confusion that Antonio Gala (cited in Dixon 1988, p. 160) and Archer (1990, p. 117) believe that this new information completely undermines the righteous motivation for the rebellion, while others hold that she may not have been raped according to a narrow, technical definition, but she has definitely been sexually assaulted, and the abuses still warrant the death of Fernán Gómez. Elman in particular has convincingly laid out the argument that the rape involves more than just sexual penetration: "the Comendador's abduction of Laurencia, in itself, constitutes rape when considered from its historical perspective" (p. 452). Ruiz Ramón, in his comments following Dixon's article, has noted that, since we have no other witness to provide testimony, there is no way to corroborate Laurencia's version of the events, and there is no particular reason for us to believe this new declaration that she has not been sexually assaulted. ${ }^{12}$

The moral, ethical, and legal thicket is only made more impenetrable by additional factors that add to the lack of a clear distinction between right and wrong. Laurencia may have been a completely innocent victim, but Robin Carter asserts that, at least in some cases, the villagers have been complicit in the abuses they have suffered: "few

\footnotetext{
10 Archer (1990, p. 111) argues that this change occurs only after Laurencia's speech, but the Regidor actually proposes that they kill the Comendador or die trying early in Act 3 (v. 1699). Even though the suggestion is rejected by the others at first, the fact that it is mentioned plants the idea of tyrannicide that is later adopted in the highly charged atmosphere created by Laurencia's emotional speech.

11 One of Carter's most convincing insights regards the relative insignificance of Leonelo, the character who comes closest to representing the philosophical stance of the theorists. By reducing this character's presence and influence, "Lope may well be hinting at the limited relevance of theoretical niceties to the problems of real life circumstances" (pp. 328 329).

12 Dixon 1988, p. 167. Dixon also has other interesting insights regarding the alleged fact that Laurencia wasn't raped: first, her ability to avoid once more the advances of the Comendador is extraordinary, and, second, the people's actions weren't so much an act of revenge for her lost honor but rather a show of solidarity in her defense (pp. 162 163; cf. 156 157). It is also worth mentioning that, even if Laurencia wasn't raped, Jacinta certainly was (Elman 1996, p. 452).
} 
individuals are totally innocent" (p. 322), and several of the women with whom the Comendador has had sexual relations agreed to his demands (p. 321; cf. Blue 1991, p. 306). Even if they were dealing from a position of subordination and weakness, it appears that many women accepted Fernán Gómez's licentious advances (vv. 1083 1084). Other villagers, in their attempts to win the favor of the Comendador with their gifts and lofty words, gave no inkling, even after numerous cases of abuse, that they were ever going to impose limits on what they would tolerate, thus giving tacit approval to any additional wrongs committed against them. Another point of confusion and indecision has to do with the question of where justice will come from. At various times it is hoped that justice will come from God ("justicia divina," vv. 1146 1147, 1250 1251, 1275 1276; see Ruiz Ramón 1991, p. 51; Fiore 1966, p. 76), from the monarchs ("El Rey sólo es señor después del cielo,” v. 1702), ${ }^{13}$ or from the people themselves either through their leaders or through the entire town itself functioning as a collective agent. From a literary and human point of view, all of these seem satisfactory, but when placed in the context of the ongoing debate over the rights of an oppressed people, it is clear that the nature and status of the one who imposes justice are crucial to the legitimacy of how one imposes justice.

Even the nature of the revenge itself raises questions as to its legitimacy. The level of intensity of the rebellion, marked by barbarity and madness (Archer 1990, p. 115), would seem to rise far above Fiore's characterization of the response as "blameless self-defense" (p. 78): they desecrate his body, dishonor his name and memory, erase his coat of arms, and sack his house, all in an attempt to inflict the greatest possible ignominy on the man whom they were praising in Act 2. The horrors inflicted upon the Comendador and his property are mentioned in the historical account by Francisco de Rades y Andrade and it would appear that Lope seemed "determined to draw our attention to the bestiality he found in his historical source." ${ }^{14}$ While he was still alive, the villagers threw him from a window so that his body would land on upturned spears and swords, they pulled his hair from his head and face and smashed in his teeth with the hilts of their swords, and they carried his body with great glee to the plaza where everyone, men and women alike, continued to desecrate his body (cited in Carter 1977, p. 327). Perhaps just as important to the current discussion is Dixon's observation that in their mad, violent frenzy, the villagers stripped the Comendador of his "cargos de justicia" (p. 164, also citing Rades). The revolt of the villagers, which Carter has called "lawless," "mob rule," "tyrannical" (p. 325), and "as sadistic as anything we have seen from the gentry" (p. 327), fails the test of justice on criterion after criterion: the motivation grounded in reason, the appeal to a neutral third party, the unimportance of one's personal feelings in the matter, and so

\footnotetext{
13 The monarchs clearly represent "justicia suprema" (Dixon 1988, p. 164), at least in secular terms. Ruiz Ramón (1991, pp. 40, 51) agrees, stating that Lope's audiences would have viewed Fernando and Isabel as iconic representations of justice. However, monarchs were considered to rule not just because of the political situation that allowed them to assume the throne but also because of divine favor. As Christopher Weimer has noted, "As divinely sanctioned rulers, Fernando and Isabel speak on God's behalf..." (p. 183). Camino (2004, p. 392) adds that the king and queen are also "the fons et origo of life and social harmony (pp. 2290 2302)."

14 Carter 1977, p. 327. As Blue as rightly noted, of course, "Critics now believe that Lope was aware of more than one possible source for his play, and the sources do not agree" (p. 312).
} 
on. Dixon agrees that the act of rebellion, even while appealing to higher authorities, and even ostensibly committed in their names, was simply an act of illegal violence accompanied by atrocities (pp. 165 166), and followed by a jubilant celebration that may be understandable from a purely human point of view but that has no place in a scenario marked by reasoned and sober justice. ${ }^{15}$

Finally, the decision by the villagers to accept the recommendation of Esteban and say only that "Fuenteovejuna lo hizo" during the inevitable investigation (even going so far as to rehearse their testimony in advance), adds yet another layer of confusion in a judicial system that seeks to define what happened in terms of black and white. In a very general sense it may be true that the death of Fernán Gómez was a function of the collective action of the village; Carter argues that "the whole village is indeed guilty" (p. 328; cf. Gómez Moriana 2000, p. 71). The notion of the collective agent, which is central to the arguments of both Kirschner and Gómez Moriana, is quite convincing from a literary point of view, but fails the test of logic and reason: "Not everyone could have killed Fernán Gómez if only because that would have been a physical impossibility" (Blue 1991, p. 306). The truth has to be that some villagers were more instrumental in his death than others, from their motivations to exhorting others to actions to the specific deeds. Moreover, is the villagers' decision not to tell the authorities all they know an action that might serve as an exemplary model or a perversion of justice? Is Elman (1996, p. 449) correct that their refusal to reveal the whole truth is tantamount to lying because the villagers are actively engaged in a conspiracy to cover up the truth? Or does one side with Ruiz Ramón, who sees in their action an example of prudence, lucidity, cleverness, and political acumen (p. 68)? Or are we to agree with Blue that "Lope may be implying the relative nature of secular truth and falsehood" (p. 312)? Since this is a work of theater and not a legal proceeding, perhaps the point is that these issues of morality and justice are left deliberately unresolved by Lope in order to produce a more engaging drama. Once again, the actions of the play are satisfying on an emotional, human level, but are contradictory to a judicial and legal context in which justice is served only by punishing the individual or individuals who have perpetrated the crime and leaving unpunished, or punishing to a lesser extent, those who are innocent or guilty of lesser offenses.

The final scenes, those most directly concerned with the search for truth and the establishment of justice, add little clarity. Why, for example, does Flores, having escaped the madness around him, make his way to the Reyes Católicos when throughout the entire play he has been a supporter of Juana in the civil war? It would seem that there are only three possible reasons, none of which are mentioned in the text: either Flores has always secretly been a supporter of Isabel even while aiding the cause of Juana as a servant of the Comendador, or the tide of the civil war has changed sufficiently so that only Fernando and Isabel can impose law, order, peace and justice in Fuenteovejuna, or the trajectory of the action, both historical and literary, is so focused on the ultimate triumph of the Reyes Católicos that it would make no sense for him to appeal to anyone else. While this last reason makes the

\footnotetext{
15 According to Ruiz Ramón (1991, p. 66), both the revenge and the torture that make up the bulk of Act 3 are cast in a carnivalesque light.
} 
most sense given the tendency towards apotheosis of the monarchs inherent in the conclusion of this play, it is still somewhat disconcerting that Flores should choose to go before the same authorities revered by the villagers in Fuenteovejuna in his attempt to bring those very villagers to justice.

More vexing is the process by which justice is established by the Reyes Católicos. Once Fernando and Isabel find out what happened, they must act; they simply cannot allow such an act of popular aggression to remain uninvestigated. They send a judge to extract the truth from the villagers, and everyone understands what that entails: questions accompanied by torture. While it appears that this kind of ordeal was an accepted practice in the collecting of evidence (Archer 1990, p. 116; Blue 1991, p. 306; Camino 2004, p. 382), the pesquisidor appears to be especially brutal, even torturing an old man, a woman, and a child, ${ }^{16}$ especially in light of the fact that he ends up with very little to show for his efforts. So strong is the resolve of the people of the village that no one, not even Mengo, says anything other than "Fuenteovejuna did it." When confronted with a moment of accountability, the peasants come together to agree upon a version of the events that is both true and false at the same time. ${ }^{17}$ Because of the effective conspiracy on the part of the villagers to keep the specifics of what happened from the legal authority, the judge fails in his attempt to discover exactly who plotted and carried out the death of the Comendador, and he reports that fact back to Fernando and Isabel. As a result, any judgment rendered by the monarchs will not have been based on the unbiased presentation of the facts of the case; in other words, the unanimous action of the people of Fuenteovejuna amounts to nothing less than obstruction of justice. Fernando and Isabel are faced with a dilemma: the murder of Fernán Gómez is a crime that clearly merits punishment (Carter 1977, p. 329). After all, since these peasants have already shown themselves to be willing and able to kill their rightful ruler, what is to keep them from rising up against these new monarchs at some future time? However, on a very pragmatic level, meting out justice in this case is impossible because the identities of the individuals directly responsible for killing the Comendador are kept secret. As the pesquisidor tells them, they must either pardon everyone or put everyone to death. Although earlier he insisted that this egregious crime would not go unpunished ("Estar puedes confiado/que sin castigo no queden," vv. 2016 2017), the King now admits that he is both unable to punish the perpetrators and unwilling to kill the entire population of the village that has just vowed allegiance to him and Isabel, so he chooses an intermediate path (Dixon 1988, p. 164): he will pardon them, taking Fuenteovejuna under his personal protection until such time as another legitimate nobleman of the Order of Calatrava

\footnotetext{
16 Archer (1990, p. 117) places the burden of cruelty during the investigation squarely on the judge sent to torture the villagers into confessing; Dixon (1988, p. 157) and Ruiz Ramón (1991, p. 74), however, see the judge as merely a representative of the king and queen, acting with the full weight of their royal authority. Camino adds an interesting observation to the discussion of the torture: because it is done in public, because it applies to all members of the community, and because of their solidarity in their responses, it serves as "a sign of social continuity and of life" (p. 392).

17 For Dixon (1988, p. 158), it is not the overthrow of the Comendador that causes the incident at Fuenteovejuna to stand out, but rather but the uniformity of the "one voice" with which the people answer the judge's questions.
} 
can assume command. Gómez Moriana (2000, p. 72) believes that the final judgment can be seen as approval of the villagers' actions, Fiore argues that natural law justifies, in a universal, cosmological sense, the rebellion and self-defense as manifestations of justice that have no need of royal sanction (p. 76), and Ruiz Ramón (1991, p. 76; cf. Dixon 1988, p. 157) views the final scene as a celebration of Fernando and Isabel as the source of justice and harmony. For Archer (1990, p. 117), however, the moral lesson is made less clear by the blanket pardon that means that, however serious the offense, no one will be punished, thus giving at least the appearance of approval. As with the other previous moments, when the Reyes Católicos are called upon to restore order, Lope once again denies us a completely satisfying sense of justice having been done.

Other questions arise when the final scene is placed in the larger context of the history of Castilla at the time of the rebellion in Fuenteovejuna. The village is in the province of Ciudad Real, clearly in the realm of Castilla, so why is the decision not pronounced by Isabel but rather by Fernando, who was king of Aragón but never served as the ruler of Castilla as long as his wife was alive? The most likely answer, of course, has to do with one of Fernando's master strokes, that of putting all the military-religious orders under his personal command in order to establish his dominion over any other nobleman who might have designs on the crown (cf. Blue 1991, p. 303), but that still doesn't explain the silence of Isabel, who herself has some problems of legitimacy. Remarkable for its absence in the criticism of this play is Isabel's role in the civil war that serves as the background action for the more local problems confronting the villagers of Fuenteovejuna. The question that the audience is specifically invited not to consider is whether or not Isabel is the legitimate queen of Castilla. Much has been made of Lope's post hoc approach to his support for Isabel who did indeed prevail and whose lineage gave Spain its current monarch in the person of Philip III. A great deal of one's perspective regarding the outcome of this play depends, however, upon whether or not one accepts Isabel's contention that her rival, Juana, was in fact not the daughter of Enrique IV. If Isabel's claim to the throne of Castile is valid, then the actions of the Comendador are in fact in the service of injustice; Fiore (1966, p. 66) states unequivocally that he "has no moral right to foment sedition against the Monarchy." However, if Juana was in fact the legitimate daughter of Enrique IV and thus the rightful heir to the throne, then one could argue that the military actions in the furtherance of Juana's claims were right and just and that those who supported Isabel were those who took the side of an unjust usurpation of the throne. This line of reasoning takes us back to the discussions of tyrannicide mentioned earlier: while it was generally conceded that people had no right to kill a legitimate ruler who was nevertheless abusive of his or her subjects, putting to death a usurper was not condemned. In other words, if Isabel was indeed a usurper, and there is no reason other than the political reality to accept her claim that Juana was illegitimate, then, according to the moral theorists of the day, it would have been more legitimate to kill Isabel as a usurper than Fernán Gómez, who may have been an evil and abusive man but had a legitimate right to rule over the village of Fuenteovejuna. Thus, right at the core of the play there is an ambiguity regarding the monarchy. 
Lope, of course, was not about to entertain this possibility, and his audience, given the "verdadero culto" of the Reyes Católicos (Pring-Mill 1962, p. 28), simply would not have stood for it. At every turn, Isabel and Fernando and their supporters are presented as representatives of the good, right, and just, while Juana's supporters are depicted as misguided at best (the youthful Maestre having been misled by the evil Comendador) and cowards or criminals at worst: consider the looting of Ciudad Real and the innocent people in it by troops loyal to Juana (vv. 509 524) and Alfonso's rather ignominious retreat to Portugal after the retaking of Ciudad Real (vv. 1940 1941). The play is not intended to be a documentary, of course, but a celebration of the memory of the king and queen who represented the brightest hopes of the Spanish people, a nostalgic recreation of a better time full of hope and optimism: "It is the myth of the Reyes Católicos, the myth of the utopian state. (...) Lope turns 'history' into myth, myth into political dream” (Blue 1991, p. 313). This iconic play may not reflect a coherent view of justice, but it does satisfy Wardropper's statement that the audience had a natural desire to see justice done (Wardropper 1956, p. 171) because everything turned out well, at least according to the narrative established through more than a century of state propaganda. Of course, as Frye noted, audience acceptance of the end of a play as "the way it should be" is not a moral pronouncement but a social one (Frye 1971, p. 167).

It is tempting to conclude that at almost every point in the play the actions undercut the notions of law and justice. There is, however, one perspective that allows the viewer to uphold the actions of the people of Fuenteovejuna as well as the actions and judgments of Fernando and Isabel, and even provides a way of looking at Lope's revisions of the historical events upon which the play is based: that of Niccolò Machiavelli. Machiavelli wrote no detailed treatise dealing specifically with justice, but it is clear, both from his incidental uses of the term as well as the larger context of his political philosophy, that justice in Machiavelli is a utilitarian notion that serves the good of the state and the accretion and retention of power by the sovereign by keeping those governed content enough that they do not rise up in revolt. Among the terms that he links to justice are necessity (Machiavelli 1998, Prince p. 88), hope (Machiavelli 1998, Prince p. 88), courage (Machiavelli 1998, Prince p. 91), law (Machiavelli 1996, Livy p. 12), prudence (Machiavelli 1996, Livy p. 12), order (Machiavelli 1996, Livy p. 24), peace and security (Machiavelli 1996, Livy p. 33), the common good, ${ }^{18}$ punishment (Machiavelli 2003, Art of War pp. 128 129), and the perpetuation of the state (Machiavelli 2003, Art of War p. 163). Machiavelli and his pragmatic approach to governing has been the subject of a few studies of Fuenteovejuna, but the focus has mostly fallen on the poor job that Fernán Gómez did in maintaining the loyalty of his subjects, essentially ruling as an autocrat and provoking the rebellion by "grave errors" (Herrera Montero 1989, p. 143). Conversely, Fernando and Isabel did a superb job of achieving their ends while still garnering the loyalty and admiration of the governed. (This latter perspective should certainly come as no surprise given Machiavelli's stated admiration for Fernando in The Prince.) Herrera Montero (1989, p. 146 147) notes a number of Machiavellian

\footnotetext{
18 On Livy 16. Forastieri studies the notion of the common good from a Thomastic perspective and in greater detail, 96 99. Cf. Fiore 1966, p. 77.
} 
means at which the Reyes Católicos excel: they use cruelty, such as in the torture of the villagers, only once, and in a way that does not lead to escalation or repetition; they show prudence and foresight in attaining their political goals; they have others do the dirty work while they pass out favors; they support the nobility without alienating the people; they take advantage of facts on the ground for their own benefit; and they act in such a manner that they actually end up creating more sympathy for themselves than resentment. In the stark terms presented to them by the pesquisidor, "o los has de perdonar/o matar la villa toda" (vv. 2381 2382), they are presented not just with a moral and judicial dilemma, but with a political one. If they grant a full pardon to the villagers, they risk alienating the powerful Order of Calatrava and making their success in the Civil War more doubtful; if they kill all the villagers, they risk losing popular support. In true Machiavellian style, they hit upon the compromise based on "practical, political convenience" (Carter 1977, p. 331), whether or not it conforms to any particular philosophical theory of justice: by torturing the villagers, the monarchs "have nodded in the direction of the Maestre, the nobles, and the Military Order. They warn the masses that law exists, order exists..." (Blue 1991, p. 309). At the same time, by pardoning the villagers, "They confirm the people's love and trust in them; they curtail the Order's power yet still draw the Maestre and his followers into their camp" (Blue 1991, p. 310). In essence, their judgment is not final at all, but rather a deferral of justice (Blue 1991, p. 296), one that ultimately leaves the question of justice hanging without further inflaming matters. When seen in a Machiavellian light, the pardon granted to the residents of Fuenteovejuna is more of a concession than an act of justice because the monarchs believe that it is better to have them as allies rather than as enemies (Herrera Montero 1989, p. 146 147). Thus, the final pronouncements of the Reyes Católicos present us with a scenario that in essence sidesteps the issue of justice while consolidating their authority.

Of importance here is not the moral and ethical judgment of each action leading to the final pronouncement; it is rather more useful to start with the historical facts and work backward. Since we know that Fernando and Isabel defeated the forces of Juana and Alfonso, any action that supports the former over the latter can thus be said to be justified, and any action that presents an obstacle to their ultimate victory must be considered unjust. One need only remember that "those nobles who failed to support the monarchy were stripped of their lands," as Elman reminds us (p. 451), to see that actions that otherwise might be considered unfair or unjust were not just approved but considered laudable if they supported the consolidation of royal power under Fernando and Isabel. Thus, the popular uprising against a supporter of Juana, his subsequent demise, and the conversions of the Maestre de Calatrava and Flores can only be seen as positive turns of events. ${ }^{19}$

\footnotetext{
19 The role of the Maestre and his pardon by the Reyes Católicos has garnered considerable attention. Carter finds the Maestre's actions to be "more obviously treasonable" (p. 330) than those of the villagers and concludes that the pardon granted to both the Maestre and the villagers "seems to point to something other than the unity of King and peasantry" and clouds any moral principles involved (p. 331). The fact that the historical Maestre was in fact an ancestor of one of Lope's patrons has not gone unnoticed. See Elman 1996, p. 453n, citing Claude Aníbal (1934, pp. 143 144), whose study provides an excellent overview of the historical incident itself. Blue provides the clearest and most complete discussion of Lope's attitude toward the Maestre, its role in the play, and its connection to contemporary court politics.
} 
This kind of approach that is pragmatic rather than dogmatic (Herrera Montero 1989, p. 148; Archer 1990, p. 117), which can be summed up as "the ends justify the means," is also reflected in Lope's changes and additions to the historical facts, the most important and necessary of which was the transformation of the Comendador from a worthy and honorable nobleman into a despicable and abusive tyrant. Lope has "altered the real-life character of Fernán Gómez from exemplary to notorious to fill the role of villain," according to Elman (1996, p. 453), who also cites Cabrera's glowing description of the historical overlord: "Noble y virtuoso, gentil y de buen juicio, ordenado y dueño de sí mismo. ! Qué lejos queda el abyecto y grosero comendador de Lope!" (Cabrera and Moros 1991, p. 113). Within the terms of the play, the elimination of such evil can only be judged to be good for the general welfare of all concerned, whether the historical figure was as reprehensible as Lope's Fernán Gómez or not. Of course, Lope created his Comendador to be not just an abusive and repugnant but exceptional individual, but a representative of larger social ills; as an example of the structural problems of a quasi-feudal system, he represents the injustice and lack of social conscience typical of the urban nobility that works at violent cross purposes with the peace and happiness otherwise found in the village (Ruiz-Ramón 1991, pp. 31, 38). While allowing those who will look closely a larger criticism of the late medieval society, Lope adroitly avoids political problems by shifting the blame for what happens to the evil and abuse inflicted upon Fuenteovejuna by one man (Ruiz Ramón 1991, pp. 20, 38), inventing an entirely new final scene in which the villagers present their case directly to the King (Carter 1977 , p. 331), and siding with the villagers by presenting their actions as justified by the abuse they have suffered and appealing to a innate sense of justice "presente en todo público teatral" (Archer 1990, p. 109). Just as history is written by the victors, so too can literature adopt a position that exalts the status quo, regardless of how that contemporary reality was achieved. Lope was nothing if not aware of the characteristics of a good play: "entertaining, well-constructed, captivating, serious and humorous" (Blue 1991, p. 311). As Lope knew only too well, in literature, especially that in which we know from the outset who is the hero and who is the villain, there is a great deal of satisfaction in seeing how the roles are played out.

\section{References}

Aníbal, C. E. (1934). The historical elements of Lope de Vega's Fuenteovejuna. PMLA, 49, 657718.

Archer, R. (1990). El pueblo, los reyes y el público: El pragmatismo dramático en Fuente Ovejuna. In War and revolution in hispanic literature (pp. 109 119). Melbourne: Voz Hispánica.

Blue, W. R. (1991). The politics of Lope's Fuenteovejuna. Hispanic Review, 59(3), 295315.

Cabrera, E., Moros, A. (1991). Fuenteovejuna: La violencia antiseñorial en el siglo XV. Barcelona: Crítica.

Camino, M. (2004). ‘¡Volvióse en luto la boda!' Ritual, torture, and the technologies of power in Lope's Fuente Ovejuna. Modern Language Review, 99(2), 382393.

Carter, R. (1977). Fuenteovejuna and Tyranny: Some problems of linking drama with political theory. Forum for Modern Language Studies, 13, 313335.

Castro, A. (1909). Introducción a "Fuenteovejuna" de Lope de Vega. Madrid: Imp. de la Última Moda. Darst, D. H. (1995). Las analogías funcionales en Fuenteovejuna. Neophilologus, 79(2), 245252. 
Dixon, V. (1988). Su majestad habla, en fin, como quien tanto ha acertado: La conclusión ejemplar de Fuente Ovejuna. Criticón, 42, 155168.

Elman, L. L. (1996). None dare call it rape: The case of Laurencia. RLA: Romance Languages Annual, 8, 449454.

Edwards, P. (Ed.). (1967). The Encyclopedia of Philosophy (vol. 8). New York: Macmillan and Free Press; London: Collier Macmillan. Rpt. 1972.

Fiore, R. (1966). Natural law in the central ideological theme of 'Fuenteovejuna'. Hispania, 49(1), 7580.

Forastieri Braschi, E. (1972). Fuenteovejuna y la justificacion. Revista de Estudios Hispanicos, 14 , 8999.

Frye, N. (1971). Anatomy of criticism: Four essays. Princeton: Princeton UP.

Gómez Moriana, A. (2000). Volviendo al protagonista colectivo en Fuenteovejuna. Revista Canadiense de Estudios Hispánicos, 25(1), 6778.

Herrera Montero, B. (1989). Fuenteovejuna de Lope de Vega y el maquiavelismo. Criticón, 45, 131153.

Kirschner, T. (1977). Evolución de la critica de Fuenteovejuna, de Lope de Vega, en el siglo XX. Cuadernos Hispanoamericanos, 320 321, 450465.

Larson, P. E. (2001). Fuente Ovejuna: History, historiography, and literary history. Bulletin of the Comediantes, 53(2), 267290.

Machiavelli, N. (2003). Art of War. (C. Lynch Ed., C. Lynch, Trans.). Chicago and London: U of Chicago P.

Machiavelli, N. (1996). Discourses on Livy. (H. C. Mansfield \& N. Tarcov, Trans.). Chicago and London: $\mathrm{U}$ of Chicago $\mathrm{P}$.

Machiavelli, N. (1988). The Prince. In Q. Skinner \& R. Price (Eds.), Cambridge: Cambridge UP.

Matas, J. (1981) El honor en Fuenteovejuna y la tragedia del comendador. Lope de Vega y los orígenes del teatro español (pp. 385 390). Madrid: EDI 6.

Pring Mill, R. D. F. (1962). Sententiousness in 'Fuente Ovejuna. Tulane Drama Review, 7, 537.

Ruiz Ramón, F. (1991). Introducción. Fuenteovejuna. By Lope de Vega. Salamanca: Colegio de España.

Sánchez Boudy, J. (1981). El derecho penal en el teatro de Lope de Vega. In Lope de Vega y los orígenes del teatro español (pp. 755 763). Madrid: EDI 6.

Vega Carpio, L. F. de (1981). Fuenteovejuna. In M. G. Profeti (Ed.), Barcelona: Planeta.

Vossler, K. (1940). Lope de Vega y su tiempo (2nd ed.). Madrid: Revista de Occidente.

Weimer, C. B. (1996). Desire, crisis, and violence in Fuenteovejuna: A Girardian perspective. In El arte nuevo de estudiar comedias: Literary Theory and Spanish Golden Age Drama (pp. 162 186). Lewisburg, PA: Bucknell UP.

Wardropper, B. W. (1956). Fuente Ovejuna: El gusto and lo justo. Studies in Philology, 53, 159171. 